\title{
Melt inclusion record of immiscibility between silicate, hydrosaline, and carbonate melts: Applications to skarn genesis at Mount Vesuvius
}

\author{
Paolo Fulignati* Dipartimento di Scienze della Terra, Università degli Studi di Pisa, via Santa Maria 53, 56126 Pisa, Italy \\ Vadim S. Kamenetsky* School of Earth Sciences and Centre for Ore Deposit Research, University of Tasmania, GPO Box \\ 252-79, Hobart, Tasmania 7001, Australia \\ Paola Marianelli* ] Dipartimento di Scienze della Terra, Università degli Studi di Pisa, via Santa Maria 53, 56126 Pisa, \\ Alessandro Sbrana* J Italy \\ Terrence P. Mernagh* Australian Geological Survey Organisation, GPO Box 378, Canberra, ACT 2601, Australia
}

\begin{abstract}
Foid-bearing syenites and endoskarn xenoliths of the A.D. 472 Vesuvius eruption represent the magma chamber-carbonate wall-rock interface. Melt inclusions hosted in crystals from these rocks offer a rare opportunity to depict the formation and the composition of metasomatic skarn-forming fluids at the peripheral part of a growing K-alkaline magma chamber disrupted by an explosive eruption. Four principal types of melt inclusions represent highly differentiated phonolite (type 1), hydrosaline melt (type 3), unmixed silicatesalt melts (type 2), and a complex chloride-carbonate melt with minor sulfates (type 4). The high-temperature $\left(700-800{ }^{\circ} \mathrm{C}\right)$ magmatic-derived hydrosaline melt is considered to be the main metasomatic agent for the skarn-forming reactions. The interaction between this melt (fluid) and carbonate wall rocks produces a Na-K-Ca carbonate-chloride melt that shows immiscibility between carbonate and chloride constituents at $\sim 700{ }^{\circ} \mathrm{C}$ in 1 atm experiments. This unmixing can be viewed as a possible mechanism for the origin of carbonatites associated with intrusion-related skarn systems.
\end{abstract}

Keywords: Vesuvius, skarn, melt inclusions, immiscibility.

\section{INTRODUCTION}

Skarns are calc-silicate rocks that typically develop at the contact between magma bodies and carbonate wall rocks and in metamorphic environments (Einaudi et al., 1981; Meinert, 1998). Endoskarn is formed by contamination and/or metasomatism of the peripheral part of an igneous body (Kerrick, 1977; Einaudi et al., 1981). Exoskarn formation has three consecutive stages: isochemical thermal metamorphism, prograde metasomatism, and retrograde hydrothermal alteration (Brown et al., 1985). Metasomatic agents for skarn-forming reactions are believed to be introduced from crystallizing and degassing magmas. These reactions result in extensive decarbonation of the country rocks and may generate sufficient permeability for the infiltration of mineralizing fluids (Kwak, 1986; Dipple and Gerdes, 1998). The origin and composition of magmatic fluids involved in the early stages of skarn formation are debated (Kwak, 1986).

The exsolution of a magmatic fluid phase from a magma emplaced at crustal levels is well shown by recent melt and fluid inclusion studies (Roedder, 1992; Frezzotti, 1992; Low-

*E-mails: Fulignati-fulignati@dst.unipi.it; Kamenetsky_Dima.Kamenetsky@utas.edu.au; Marianelli_marianelli@dst.unipi.it; Sbrana_sbrana@ dst.unipi.it; Mernagh_Terry.Mernagh@agso.gov. au. enstern, 1994; Yang and Bodnar, 1994; De Vivo et al., 1995; Kamenetsky et al., 1999; Thomas et al., 2000). The coexistence in phenocrysts of silicate melt and saline melt inclusions and the presence of multiphase inclusions (silicate glass + hydrosaline melt + volatiles) with highly variable volume ratios have been considered as strong evidence for immiscibility between silicate and nonsilicate melts during magma crystallization (Frezzotti, 1992, 2001; De Vivo et al., 1995). Magmatic inclusion evidence also exists for the exsolution of fluids from shallow magma chambers of alkaline volcanoes (De Vivo et al., 1995; Belkin et al., 1996; Fulignati et al., 1998). Exsolved hypersaline fluids that sequester oreforming elements (e.g., $\mathrm{Au}, \mathrm{Ag}, \mathrm{Cu}, \mathrm{Pb}, \mathrm{Zn}$, Sn) from magmas (Candela and Piccoli, 1995; Audetat et al., 1998; Ulrich et al., 1999) may play an important role in the genesis of hydrothermal ore deposits, e.g., $\mathrm{Cu}-\mathrm{Au}-\mathrm{Mo}$ porphyries and skarns (Kwak, 1986; Hedenquist and Lowenstern, 1994; Cline and Bodnar, 1994; Kamenetsky et al., 1999).

This paper reports on fluid exsolution from the peripheral part of the A.D. 472 (Pollena eruption) Vesuvius magma chamber, recorded in a series of melt and fluid inclusions in phenocrysts from the magma chamber and related skarn rocks. These inclusions clearly demonstrate a transition from the silicate melt to $\mathrm{Si}$ - poor, volatile-rich phases (carbonate-chloridesulfate melt) that form and further react with carbonate wall rocks at the margin of the magma chamber, as part of skarn formation.

\section{VESUVIUS: MAGMA CHAMBER AND A.D. 472 ERUPTION SAMPLES}

The Vesuvius magmatic system is characterized by the presence of shallow reservoirs hosted within the Mesozoic carbonate basement (dolostone and limestone) that are periodically supplied with relatively hot (1150$1200{ }^{\circ} \mathrm{C}$ ) mafic magma batches (Marianelli et al., 1995). Magma batches thermally equilibrate, crystallize, and mix with cooler resident magmas, forming zoned reservoirs. The chamber melts may reach highly alkalic phonolite composition with temperatures $\sim 800-900{ }^{\circ} \mathrm{C}$ (Cioni et al., 1998). The resident magmas cause chemical reactions, metasomatic and thermometamorphic transformations inducing the formation of a complexly stratified interface between the magma chamber and country rocks. The outer margin of the magma chamber (Fig. 1), consisting of crystallized magmas (from glass-bearing fergusites to foid-bearing K-syenites), continuously grades into carbonate country rocks through a skarn shell and thermometamorphic marble (Fulignati et al., 1998, 2000a, 2000b).

Our study focuses on the A.D. 472 subPlinian eruption products (young-stage magma chamber, after Cioni et al., 1998), which vary in composition from early leucititic phonolite $\left(\sim 900{ }^{\circ} \mathrm{C}\right)$ to later leucititic phonotephrite and contain cognate foid-bearing syenitic and calc-silicate (skarn) xenoliths. Syenites are nearly holocrystalline, nonequigranular rocks composed of K-feldspar, leucite, K-pargasitic amphibole, biotite, salitic clinopyroxene, melanitic garnet, interstitial nepheline, and accessory sphene and fluorapatite. Skarn xenoliths consist of fassaitic clinopyroxene, phlogopite, nepheline, calcite, and accessory apatite. On the basis of previous studies of the magma chamber-wall-rock interface in other Vesuvius eruptions (Belkin et al., 1985; Fulignati et al., 1998, 2000a, 2000b), and in accord with the results 


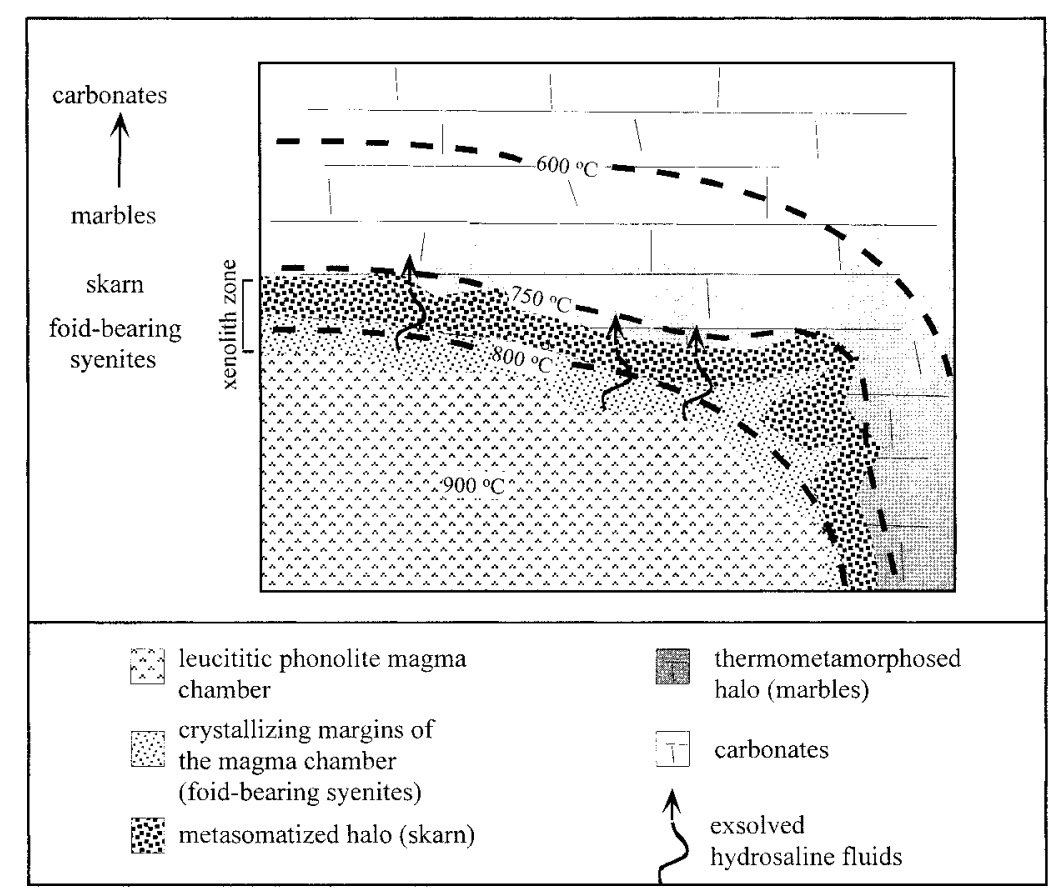

Figure 1. Schematic section of upper part of A.D. 472 shallow magma chamber-wall-rock transition at Vesuvius. Dashed lines represent approximation of isotherms in surroundings of chamber inferred from this and previous (Marianelli, 1995; Fulignati et al., 2000a) studies.

of Belkin and De Vivo (1993), we envisage that these rocks derived from the margin and the immediate surroundings of the magma chamber (Fig. 1).

\section{MELT INCLUSION STUDIES}

\section{Inclusion Types}

Several types of coexisting primary melt inclusions were identified in foid-bearing syenites (types 1 to 3 ) and skarn samples (types 2 and 4$)^{1}$.

Type 1 comprises two-phase melt inclusions (brown silicate glass and one to several small shrinkage bubbles) hosted in nepheline and K-feldspar (Fig. 2A).

Type 2 comprises multiphase melt inclusions in leucite and nepheline, consisting of brown or clear silicate glass and one (Fig. 2, C-E) or multiple (Fig. 2B) fluid-bearing globule(s). Globules contain a vapor bubble and heterogeneous crystalline material. When the bubble dominates a globule, the solids can be seen protruding from the bubble into the silicate glass, or forming a shell on the bubbleglass interface (Fig. 2, B-E). The glass/globule ratio is highly variable and in many inclusions globules are volumetrically significant (Fig. 2, D and E).

Type 3 are multiphase inclusions in neph-

${ }^{1}$ GSA Data Repository item 2001120, Appendix Table 1, Composition of melt inclusions, is available on request from Documents Secretary, GSA, P.O. Box 9140, Boulder, CO 80301-9140, editing@geosociety. org, or at www.geosociety.org/pubs/ft2001.htm. eline from syenite (Fig. 2F). Type 4 are multiphase inclusions in nepheline and clinopyroxene from the endoskarn xenolith (Fig. 2G). Inclusions of both types are similar in appearance and often coexist in trapping planes with type 2 inclusions. They have different daughter solids, a deformed bubble, and a small amount of interstitial liquid. Crystals with cubic habits (chlorides?), birefringent euhedral phases (silicates, sulfates, and carbonates?), and opaque minerals (sulfides and oxides?) are always present among the solids.

\section{Heating Experiments with Melt Inclusions}

The most significant results from heating experiments for type 3 and type 4 inclusions are described here.

Cubic crystals (chlorides?) in type 3 inclusions melt completely at $510-590{ }^{\circ} \mathrm{C}$ (number of measurements, $\mathrm{N}=52$ ). Melting of other daughter minerals including opaque phases and disappearance of the vapor bubble always occur at higher temperatures $\left(690-810{ }^{\circ} \mathrm{C}, \mathrm{N}\right.$ $=70$ ). It is interesting that in the coexisting type 2 inclusions the sequence and temperatures of phase transformations in the vaporand crystal-bearing globules are similar to those observed in type 3 inclusions.

Heating of the nepheline-hosted type 4 inclusions produces complete melting of daughter crystals at $800-830{ }^{\circ} \mathrm{C}(\mathrm{N}=92)$ in all inclusions (Fig. 3), followed by vapor-bubble homogenization between 860 and $885^{\circ} \mathrm{C}$, but only in a few inclusions. Some solids (possi-

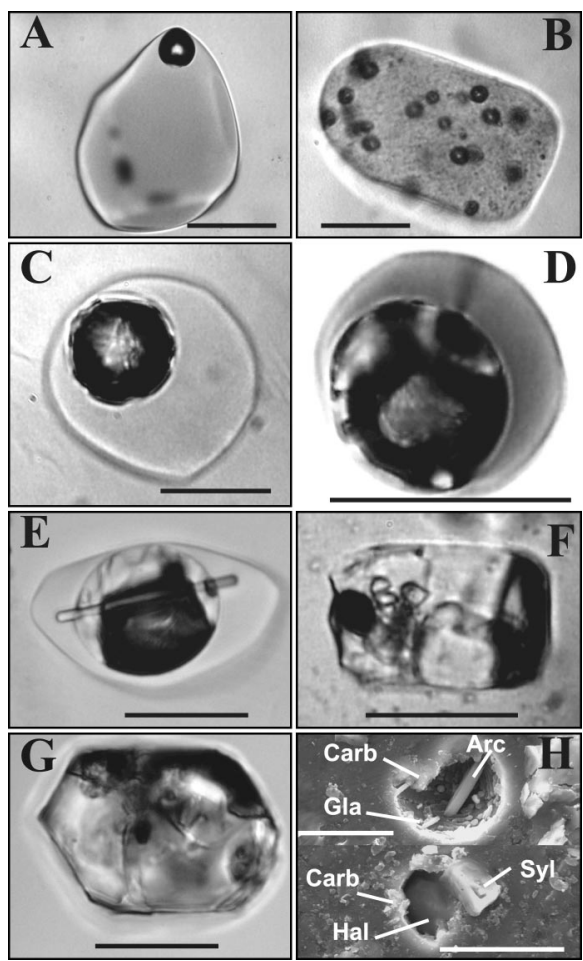

Figure 2. Representative melt inclusions in magmatic and skarn minerals. A: Type 1 silicate two-phase (glass + shrinkage bubble) inclusion. B, C, D: Type 2 inclusions from syenites. E: Type 2 inclusion from endoskarn with variable proportions of silicate glass and nonsilicate, vapor-bearing globules (see text for details). F and G: Type 3 and type 4, respectively, multiphase inclusions containing translucent (isotropic and birefringent) and opaque daughter minerals, deformed vapor bubble(s), and interstitial liquid. H: Scanning electron microscope images of exposed type 4 inclusions, containing chlorides (halite [Hal] and sylvite [Syl]), sulfates (glaserite [Gla] and arcanite [Arc]), and $\mathrm{Na}-\mathrm{Ca}$ carbonate (Carb). All scale bars are $20 \mu \mathrm{m}$. All microphotographs were taken before heating experiments.

bly heterogeneously trapped silicates) may persist to higher temperatures $\left(840-980{ }^{\circ} \mathrm{C}\right.$; N $=59$ ). Subsequently, rapid cooling (e.g., 50 ${ }^{\circ} \mathrm{C} / \mathrm{min}$ ) of type 4 inclusions always results in immiscibility between two clear liquids (Fig. 3) at $\sim 670-700{ }^{\circ} \mathrm{C}(\mathrm{N}=38)$. The new melt usually forms a single globule around a vapor bubble (Fig. 3), but sometimes numerous globules form and then coalesce. A globule of this second melt is always a site of nucleation of the opaque phase (sulfide?) at $<650{ }^{\circ} \mathrm{C}$. Below $600{ }^{\circ} \mathrm{C}$ rapid crystallization within two unmixed liquids obscures phase boundaries and deforms the vapor bubble. Repeated heating and cooling on the same inclusion shows that the immiscibility is reversible at a constant temperature $\left(\sim 670-700{ }^{\circ} \mathrm{C}\right)$.

\section{Inclusion Compositions}

The silicate glasses in type 1 melt inclusions have a K-phonolitic composition similar 


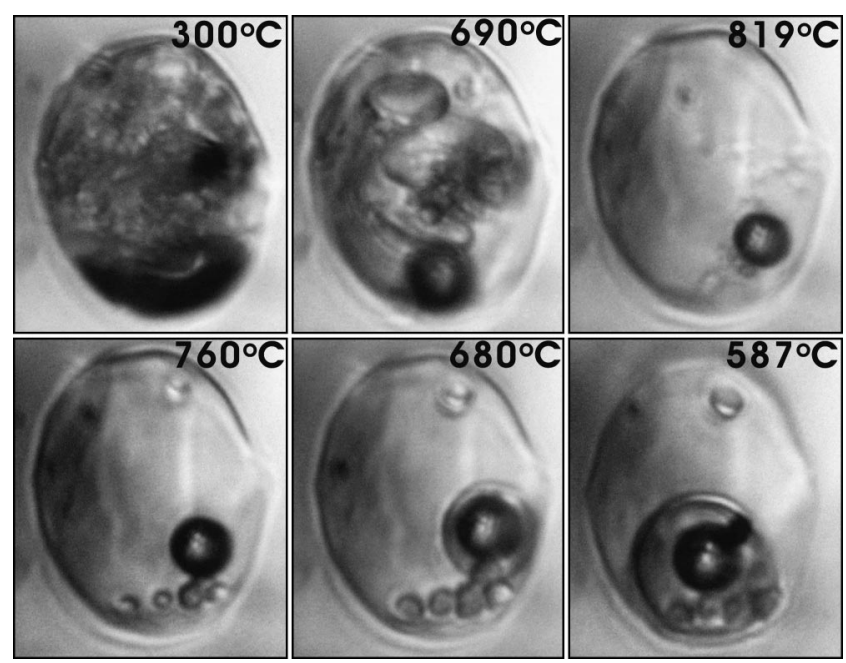

Figure 3. Microphotographs illustrating behavior of type 4 melt inclusion during heating (top row) and cooling (bottom row) experiments at different temperatures (Linkam TS1500 heating stage, University of Tasmania). Note unmixing between two liquids at temperatures $<680{ }^{\circ} \mathrm{C}$ : globule of chloride melt (around vapor bubble) is enclosed in $\mathrm{Na}-\mathrm{K}-\mathrm{Ca}$ carbonate melt. In this experiment opaque phase (sulfide?) formed at 587 ${ }^{\circ} \mathrm{C}$ inside globule of chloride melt. Inclusion size is $33 \times 27 \mu \mathrm{m}$. Cooling rate was $\sim 50^{\circ} \mathrm{C} / \mathrm{min}$.

to that of the melt inclusions found in the A.D. 472 juvenile products (Table 1). In contrast, the compositions of glasses in type 2 melt inclusions from syenites (extremely high $\mathrm{Al}_{2} \mathrm{O}_{3}$, $\mathrm{Na}_{2} \mathrm{O}$, and $\mathrm{Cl}$; Table 1 [and see footnote 1]) have not been previously recorded in the Vesuvius rocks and glasses (e.g., Cioni et al., 1998). According to laser Raman spectroscopy, fluid-bearing globules in type 2 melt inclusions from syenites contain $\mathrm{CO}_{2}$ and a complex mixture of nonsilicate minerals, including chlorides, sulfates, carbonates, bicarbonates, and fluorocarbonates (Table 2).

The daughter mineral assemblage of type 3 inclusions is represented by the same phases found in the globules inside type 2 melt inclusions from syenites, with the addition of fluoride and sulfides (Table 2). Dissolution temperatures of inferred halite in these inclusions correspond to $61-72 \mathrm{wt} \% \quad \mathrm{NaCl}_{\text {equiv }}$ salinity.

Type 4 inclusions in the endoskarn minerals have a very complex paragenesis of daughter minerals (chlorides, carbonates, sulfates, and sulfides; Table 2). Accordingly, the two liquids unmixed during cooling in experiments
(Fig. 3) are cautiously identified as a globule of $\mathrm{K}-\mathrm{Na}$ chloride melt in a larger volume of the Na-K-Ca carbonate melt with minor sulfates present (Fig. 2H).

\section{DISCUSSION AND CONCLUSIONS}

Foid-bearing syenite and endoskarn xenoliths of the A.D. 472 eruption of Vesuvius represent the magma chamber-wall-rock interface, where complex skarn reaction processes occur. Thus, melt inclusions in these rocks offer a rare opportunity to illustrate the formation and composition of metasomatic, skarnforming agents at the peripheral part of a growing K-alkaline magma chamber disrupted by an explosive eruption. The syneruptive quenching of magma and exotic xenoliths has preserved information about the earliest stages and consequences of skarn reaction processes.

We consider type 1 melt inclusions (Fig. $2 \mathrm{~A}$; Table 1) as representative of the late magmatic stage silicate melt (highly differentiated phonolite) that may have reacted with the carbonate country rocks by itself and/or via fluids derived from this melt. These interactions produce another silicate melt enriched in nonsil-
TABLE 1. REPRESENTATIVE ANALYSES OF SILICATE GLASSES IN UNHEATED MELT INCLUSIONS

\begin{tabular}{|c|c|c|c|c|c|c|c|c|c|c|}
\hline Host mineral & $\mathrm{SiO}_{2}$ & $\mathrm{TiO}_{2}$ & $\mathrm{Al}_{2} \mathrm{O}_{3}$ & $\mathrm{FeO}^{*}$ & $\mathrm{MnO}$ & $\mathrm{MgO}$ & $\mathrm{CaO}$ & $\mathrm{Na}_{2} \mathrm{O}$ & $\mathrm{K}_{2} \mathrm{O}$ & $\mathrm{Cl}$ \\
\hline \multicolumn{11}{|c|}{ Type 1 melt inclusions } \\
\hline K-feldspar & $\overline{51.81}$ & 0.24 & 22.37 & 2.70 & 0.33 & 0.09 & 3.90 & 8.88 & 8.85 & 0.83 \\
\hline Nepheline & 53.92 & 0.48 & 22.36 & 2.38 & 0.41 & 0.23 & 1.83 & 8.11 & 9.58 & 0.70 \\
\hline \multicolumn{11}{|c|}{ Type 2 melt inclusions } \\
\hline Leucite & 49.16 & 0.75 & 26.60 & 2.17 & 0.25 & 0.15 & 2.62 & 13.35 & 3.91 & 1.03 \\
\hline \multicolumn{11}{|c|}{ Melt inclusions in A.D. 472 juvenile fraction $\$$} \\
\hline Fe-salite & 53.11 & 0.11 & 22.58 & 3.15 & $\mathrm{Id}^{\dagger}$ & 0.43 & 3.36 & 7.79 & 8.67 & 0.80 \\
\hline \multicolumn{11}{|c|}{$\begin{array}{l}\text { Note: Major elements and } \mathrm{Cl} \text { (wt\%) of Ml glasses and minerals were analyzed by SEM-EDS technique using } \\
\text { Philips XL30 with EDAX DX4 at } 20 \mathrm{kV} \text { accelerating energy, } 0.1 \mathrm{nA} \text { beam current, } 100 \mathrm{~s} \text { live time (a raster area } \\
f \sim 10 \times 10 \mu \mathrm{m} \text { was employed on glass). All analyses are normalized to } 100 \text { wt } \% \text { due to the EDAX software } \\
\text { sed. } \\
{ }^{*} \mathrm{All} \text { Fe as FeO. } \\
{ }^{\dagger} \mathrm{ld}=\text { below detection limit. } \\
\text { §Data from Marianelli (1995). }\end{array}$} \\
\hline
\end{tabular}

icate (e.g., carbonates and chlorides) components, and probably unstable in a cooling environment. Immiscibility or unmixing in this melt is well represented by type 2 melt inclusions that consist of silicate glass and nonsilicate (chloride-carbonate-sulfate) $\mathrm{CO}_{2}$ bearing globules (hereafter "salt melt"). The beginning of unmixing, i.e., the formation of numerous tiny salt melt globules, immiscible with a silicate melt, is possibly shown by the inclusion in Figure 2B. The high variability in the silicate melt/salt melt ratios in type 2 melt inclusions (Fig. 2, B-E) clearly indicates (according to the definitions in Roedder, 1984; Frezzotti, 2001) heterogeneous trapping of these two coexisting phases.

The next evolutionary stage, as represented by type 3 melt inclusions (Fig. 2F), is dominated by the salt melt phases. A close genetic relationship between silicate and salt melts is inferred here from the fact that glass-bearing type 2 and glass-free type 3 melt inclusions coexist within the growth planes and have a similar assemblage of daughter minerals (Table 2). We consider magmatic-derived hightemperature $\left(700-800{ }^{\circ} \mathrm{C}\right)$ melts or fluids similar in composition to type 3 inclusions to be the most important in the skarn-forming reactions. In the Vesuvius skarn, the main compounds of metasomatic agents are represented by chlorides and carbonates with minor amounts of sulfates, sulfides, and fluorides. The presence of parisite and fluorite indicates that, in addition to chlorine, fluorine may play an important role in the transport of metal and rare earth elements (REEs), as has been implicated for the origin of REE mineralization associated with alkalic and carbonatite complexes (e.g., Birkett and Sinclair, 1998, and references therein).

The interaction between early high-temperature hypersaline fluids and carbonate country rocks is best recorded in inclusions in the endoskarn minerals (type 4 inclusions, Fig. 2G). In these we found a Na-K-Ca carbonate-chloride melt (Fig. $2 \mathrm{H}$ ) that is a subject to immiscibility at $\sim 690{ }^{\circ} \mathrm{C}$, as demonstrated by our 1 atm heating and cooling experiments (Fig. 3). However, whether carbonate-chloride unmixing occurs in a given natural system depends on the cooling and pressure conditions. Therefore, we consider that the interaction between magmatic brines and carbonate wall rocks, in addition to inducing metasomatic reactions, can be viewed as a possible mechanism for carbonate melting, as suggested by Lentz (1998, 1999), for the formation of carbonatite melts associated with alkalic intrusions.

\section{ACKNOWLEDGMENTS}

We thank T. Crawford and P. Davidson for critically reading this manuscript and for useful comments. The manuscript benefited immensely from the formal reviews by D.R. Lentz and J.B. Lowenstern. This research was sup- 
TABLE 2. PHASE COMPOSITION OF MELT INCLUSIONS

\begin{tabular}{|c|c|c|c|c|}
\hline & \multicolumn{4}{|c|}{ Daughter minerals } \\
\hline & \multicolumn{2}{|c|}{ Laser Raman spectroscopy } & \multicolumn{2}{|c|}{ SEM-EDS } \\
\hline $\begin{array}{c}\text { Type } 2 \\
\text { (foid-bearing syenite) }\end{array}$ & $\begin{array}{l}\text { calcite } \\
\text { nahcolite } \\
\text { strontianite } \\
\text { parisite } \\
\text { sulfates } \\
\text { salts }\end{array}$ & $\begin{array}{c}{\left[\mathrm{CaCO}_{3}\right]} \\
{\left[\mathrm{NaHCO}_{3}\right]} \\
{\left[\mathrm{SrCO}_{3}\right]} \\
{\left[\mathrm{Ca}(\mathrm{Ce}, \mathrm{La})_{2}\left(\mathrm{CO}_{3}\right)_{3} \mathrm{~F}_{2}\right]}\end{array}$ & $\begin{array}{l}\text { halite } \\
\text { anhydrite }\end{array}$ & $\begin{array}{c}{[\mathrm{NaCl}]} \\
{\left[\mathrm{CaSO}_{4}\right]}\end{array}$ \\
\hline $\begin{array}{c}\text { Type } 3 \\
\text { (foid-bearing syenite) }\end{array}$ & $\begin{array}{l}\text { calcite } \\
\text { dolomite } \\
\text { nahcolite } \\
\text { strontianite } \\
\text { witherite } \\
\text { parisite } \\
\text { marcasite } \\
\text { sulfates } \\
\text { salts }\end{array}$ & $\begin{array}{c}{\left[\mathrm{CaCO}_{3}\right]} \\
{\left[\mathrm{CaMg}\left(\mathrm{CO}_{3}\right)_{2}\right]} \\
{\left[\mathrm{NaHCO}_{3}\right]} \\
{\left[\mathrm{SrCO}_{3}\right]} \\
{\left[\mathrm{BaCO}_{3}\right]} \\
{\left[\mathrm{Ca}\left(\mathrm{Ce}, \mathrm{La}_{2}\left(\mathrm{CO}_{3}\right)_{3} \mathrm{~F}_{2}\right]\right.} \\
{\left[\mathrm{FeS}_{2}\right]}\end{array}$ & $\begin{array}{l}\text { halite } \\
\text { sylvite } \\
\text { anhydrite } \\
\text { nahcolite } \\
\text { fluorite }\end{array}$ & $\begin{array}{c}{[\mathrm{NaCl}]} \\
{[\mathrm{KCl}]} \\
{\left[\mathrm{CaSO}_{4}\right]} \\
{\left[\mathrm{NaHCO}_{3}\right]} \\
{\left[\mathrm{CaF}_{2}\right]}\end{array}$ \\
\hline $\begin{array}{c}\text { Type } 4 \\
\text { (endoskarn) }\end{array}$ & & & $\begin{array}{l}\text { halite } \\
\text { sylvite } \\
\text { unknown chloride } \\
\text { anhydrite } \\
\text { glaserite } \\
\text { arcanite } \\
\text { Fe-Cu-Zn-Pb sulfide }\end{array}$ & $\begin{array}{c}{[\mathrm{NaCl}]} \\
{[\mathrm{KCl}]} \\
{[? \mathrm{Cl}]} \\
{\left[\mathrm{CaSO}_{4}\right]} \\
{\left[\left(\mathrm{Na}, \mathrm{K}_{2} \mathrm{SO}_{4}\right]\right.} \\
{\left[\mathrm{K}_{2} \mathrm{SO}_{4}\right]}\end{array}$ \\
\hline & & & $\mathrm{Na}-\mathrm{Ca}$ carbonate & \\
\hline
\end{tabular}

Note: Daughter minerals in melt inclusions were identified by SEM-EDS (using a Philips XL30 with EDAX DX4, Dipartimento di Scienze della Terra, University of Pisa) and laser Raman spectroscopy (using a Dilor SuperLabram spectrometer equipped with a holographic notch filter, 600 and $1800 \mathrm{~g} / \mathrm{mm}$ gratings, and a liquid $\mathrm{N}_{2}$ cooled, $2000 \times 450 \mathrm{CCD}$ detector, Australian Geological Survey Organisation). For SEM-EDS investigation on type 4 melt inclusions, crystals were mounted in epoxy and gradually ground to the point of exposure of the inclusions. In order to avoid the loss of salts the polishing was carried out using kerosene and water was never used.

ported by a Gruppo Nazionale per la Vulcanologia-Istituto Nazionale di Geofisica e Vulcanologia (Italy) grant to A. Sbrana and a Centre for Ore Deposit Research (Australia) grant to V. Kamenetsky. T. Mernagh publishes with the permission of the Chief Executive Officer of the Australian Geological Survey Organisation.

\section{REFERENCES CITED}

Audetat, A., Gunther, D., and Heinrich, C.A., 1998, Formation of a magmatic-hydrothermal ore deposit: Insights with LA-ICP-MS analysis of fluid inclusions: Science, v. 279, p. 2091-2094

Belkin, H.E., and De Vivo, B., 1993, Fluid inclusion studies of ejected nodules from Plinian eruptions of $\mathrm{Mt}$ Somma-Vesuvius: Journal of Volcanology and Geothermal Research, v. 58, p. 89-100.

Belkin, H.E., De Vivo, B., Roedder, E., and Cortini, M., 1985, Fluid inclusion geobarometry from ejected Mt Somma-Vesuvius nodules: American Mineralogist, v. 70, p. $288-303$.

Belkin, H.E., De Vivo, B., Lima, A., and Torok, K., 1996 Magmatic (silicates/saline/sulfur-rich/ $\mathrm{CO}_{2}$ ) immiscibility and zirconium and rare-earth element enrichment from alkaline magma chamber margins: Evidence from Ponza Island, Pontine Archipelago, Italy: European Journal of Mineralogy, v. 8, p. 1401-1420.

Birkett, T.C., and Sinclair, W.D., 1998, Rare-metal replacement deposits (skarn and fenites) associated with alkalic and carbonatite complexes, in Lentz, D.R., ed., Mineralized intrusion-related skarn systems: Mineralogical Association of Canada Short Course 26, p. 445-473.

Brown, P.E., Bowman, J.R., and Kelly, W.C., 1985, Petrologic and stable isotope constraints on the source and evolution of skarn-forming fluids at Pine Creek, California: Economic Geology, v. 80, p. 72-95.
Candela, P.A., and Piccoli, P.M., 1995, Model ore-metal partitioning from melts into vapor and vapor/brine mixtures, in Thompson, J.F.H., ed., Magmas, fluids, and ore deposits: Mineralogical Association of Canada Short Course 23, p. 101-127.

Cioni, R., Marianelli, P., and Santacroce, R., 1998, Thermal and compositional evolution of the shallow magma chambers of Vesuvius: Evidence from pyroxene phenocrysts and melt inclusions: Journal of Geophysical Research, v. 103, p. 18277-18 294.

Cline, J.S., and Bodnar, R.J., 1994, Direct evolution of brine from a crystallizing silicic melt at the Questa, New Mexico, molybdenum deposit: Economic Geology, v. 89, p. 1780-1802.

De Vivo, B., Torok, K., Ayuso, R.A., Lima, A., and Lirer, L., 1995, Fluid inclusion evidence for magmatic silicate/saline $/ \mathrm{CO}_{2}$ immiscibility and geochemistry of alkaline xenoliths from Ventotene Island, Italy: Geochimica et Cosmochimica Acta, v. 59, p. 2941-2953.

Dipple, G.M., and Gerdes, M.L., 1998, Reaction-infiltration feedback and hydrodynamics at the skarn front, in Lentz, D.R., ed., Mineralized intrusion-related skarn systems: Mineralogical Association of Canada Short Course 26, p. 71-97.

Einaudi, M.T., Meinert, L.D., and Newberry, R.J., 1981, Skarn deposits: Economic Geology, 75th Anniversary Volume, p. 317-391.

Frezzotti, M.L., 1992, Magmatic immiscibility and fluid phase evolution in the Mount Genis granite (southeastern Sardinia, Italy): Geochimica et Cosmochimica Acta, v. 56, p. 21-33.

Frezzotti, M.L., 2001, Silicate-melt inclusions in magmatic rocks: Applications to petrology: Lithos, v. 55, p. 273-299.

Fulignati, P., Gioncada, A., and Sbrana, A., 1998, The 79 A.D. Vesuvius magma chamber: A SEM-EDS study of daughter minerals in hypersaline fluid inclusions from cognate syenites: Neues Jahrbuch für Mineralogie Monashefte, v. 1998, p. 403-416.

Fulignati, P., Marianelli, P., Santacroce, R., and Sbrana, A., 2000a, The skarn shell of the 1944 Vesuvius magma chamber. Genesis and P-T-X conditions from melt and fluid inclusion data: European Journal of Mineralogy, v. 12, p. 1025-1039.

Fulignati, P, Marianelli, P, and Sbrana, A, 2000b, Glassbearing felsic nodules from the crystallizing sidewalls of the 1944 Vesuvius magma chamber: Mineralogical Magazine, v. 64, p. 481-496.

Hedenquist, J.W., and Lowenstern, J.B., 1994, The role of magmas in the formation of hydrothermal ore deposits: Nature, v. 370, p. 519-527.

Kamenetsky, V.S., Wolfe, R.C., Eggins, S.M., Mernagh, T.P., and Bastrakov, E., 1999, Volatile exsolution at the Dinkidi $\mathrm{Cu}-\mathrm{Au}$ porphyry deposit, Philippines: A melt-inclusion record of the initial ore-forming process: Geology, v. 27, p. 691-694.

Kerrick, D.M., 1977, The genesis of zoned skarns in the Sierra Nevada, California: Journal of Petrology, v. 18 , p. $144-181$

Kwak, T.A.P., 1986, Fluid inclusions in skarns (carbonate replacement deposits): Journal of Metamorphic Geology, v. 4, p. 363-384.

Lentz, D.R., 1998, Late-tectonic U-Th-Mo-REE skarn and carbonatitic vein-dyke systems in the southwestern Grenville Province: A pegmatite-related pneumatolytic model linked to marble melting (limestone syntexis), in Lentz, D.R., ed., Mineralized intrusionrelated skarn systems: Mineralogical Association of Canada Short Course 26, p. 519-657.

Lentz, D.R., 1999, Carbonatite genesis: A reexamination of the role of intrusion-related pneumatolytic skarn processes in limestone melting: Geology, v. 27 , p. $335-338$

Lowenstern, J.B., 1994, Chlorine, fluid immiscibility, and degassing in peralkaline magmas from Pantelleria, Italy: American Mineralogist, v. 79, p. 353-369.

Marianelli, P., 1995, La camera magmatica del Vesuvio: Processi petrogenetici e dinamica eruttiva [Ph.D. thesis]: Pisa, Italy, Università degli Studi di Pisa, 206 p.

Marianelli, P., Metrich, N., Santacroce, R., and Sbrana, A., 1995, Mafic magma batches at Vesuvius: A glass inclusion approach to the modalities of feeding stratovolcanoes: Contributions to Mineralogy and $\mathrm{Pe}$ trology, v. 120, p. 159-169.

Meinert, L.D., 1998, A review of skarns that contain gold, in Lentz, D.R., ed., Mineralized intrusion-related skarn systems: Mineralogical Association of Canada Short Course 26, p. 359-414.

Roedder, E., 1984, Fluid inclusions: Mineralogical Society of America Reviews in Mineralogy, v. 12, 644 p.

Roedder, E., 1992, Fluid inclusion evidence for immiscibility in magmatic differentiation: Geochimica et Cosmochimica Acta, v. 56, p. 5-20.

Thomas, R. Webster, J.D , and Heinrich, W., 2000, Melt inclusions in pegmatite quartz: Complete miscibility between silicate melts and hydrous fluids at low pressure: Contributions to Mineralogy and Petrology, v. 139 , p. $394-401$.

Ulrich, T., Gunther, D., and Heinrich, C.A., 1999, Gold concentrations of magmatic brines and the metal budget of porphyry copper deposits: Nature, v. 399, p. 676-679.

Yang, K., and Bodnar, R.J., 1994, Magmatic-hydrotherma evolution in the "bottoms" of porphyry copper system: Evidence from silicate melt and aqueous fluid inclusions in granitoid intrusions in the Gyeongsang basin, South Korea: International Geology Review, v. 36 , p. $608-628$

Manuscript received March 7, 2001

Revised manuscript received June 28, 2001

Manuscript accepted July 20, 2001

Printed in USA 